\title{
Peran Satlantas Polres Rembang Dalam Menanggulangi Tingginya Kecelakaan Akibat Parkir Liar (Studi Kasus di Kabupaten Rembang) \\ Bhakti Satriya Perdana Sugiyanto ${ }^{*}$, Gunarto ${ }^{* *}$
}

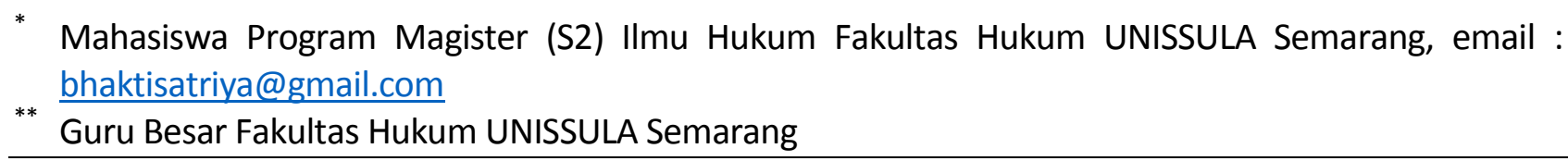

\begin{abstract}
ABSTRAKSI
Kepolisian Negara Republik Indonesia atau biasa secara singkat Polri adalah instrumen negara yangberperan dalam menjaga keamanan dan ketertiban masyarakat, menegakkan hukum, dan memberikan perlindungan, perlindungan dan pelayanan kepada masyarakat dalam rangka menjaga keamanan dalam negeri. Unit lalu lintas itu sendiri merupakan bagian dari Polri yang merupakan unsur pelaksana utama di bawah Kapolri. Kecelakaan merupakan peristiwa yang tak terduga dan tidak disengaja, sementara selanjutnya dijelaskan dalam undang-undang bahwa kecelakaan lalu lintas adalah kejadian tak terduga dan tidak disengaja yang melibatkan kendaraan dengan atau tanpa pengguna jalan lainnya yang mengakibatkan manusia dan / atau kehilangan harta benda.
\end{abstract}

Kata kunci : kecelakaan, parkir liar

\section{ABSTRACT}

Police of the Republic of Indonesia or commonly in brief Polri is a state instruments that plays a role in maintaining security and public order, upholding the law, and providing protection, protection and service to the community in the framework of maintaining internal security.Traffic unit itself is part of the Police which is the main task implementing element under the Police ChiefResort.An accident is an unexpected and unhappened event, while further described in law that a traffic accident is an unexpected and accidental incident involving a vehicle with or without other road users resulting in human and / or loss of property.

Keywords: accident, illegal parking

\section{PENDAHULUAN.}

Indikasi tingginya produktivitas dan perekonomian di suatu daerah dapat diliat dari tingginya aktvitas lalu lintas, menurut paham undang-undang Nomor 22 Tahun 2009 tentang Lalu Lintas dan Angkutan Jalan, Lalu Lintas adalah gerak kendaraan dan orang diruang lalu lintas ${ }^{1}$. Aktifitas lalu lintas sendiri berarti suatu kegiatan dari sistem yang meliputi lalu lintas, jaringan lalu lintas dan angkutan jalan, prasarana lalu lintas dan angkutan jalan, pengemudi, kendaraan, pengguna jalan lainnya serta pengelolaannya ${ }^{2}$ yang keseluruhannya tergabung di dalam suatu sistem yang disebut dengan sistem transportasi lalu lintas.

Sistem lalu lintas pada dasarnya terdiri dari 3 (tiga) komponen dasar yang harus diketahui oleh setiap pengguna jalan. Komponen lalu lintas tersebut adalah: manusia sebagai pengguna, kendaraan; dan jalan yang keseluruhannya saling berinteraksi dalam pergerakan kendaraan yang memenuhi

\footnotetext{
${ }^{1}$ Lihat Pasal 1 ayat 3 Undang - undang Nomor 22 Tahun 2009 tentang Lalu Lintas dan Angkutan Jalan

${ }^{2}$ Bandingkan dengan Pasal 1 ayat 1 Undang - undang Nomor 22 Tahun 2009 tentang Lalu Lintas dan Angkutan Jalan
} 
persyaratan kelaikan dikemudikan oleh pengemudi dengan mengikuti aturan lalu lintas yang ditetapkan berdasarkan peraturan perundang-undangan yang mengaturnya.

Sebagai suatu sistem lalu lintas itu sendiri, tentunya dibutuhkan sinkronisasi antara komponenkomponen lalu lintas didalamnya agar lalu lintas dapat berjalan sesuai dengan harapan yang sebenarnya.Tujuan dari dibuatnya suatu sistem adalah untuk memudahkan ruang gerak agar tertib dan teratur bukan malah sebaliknya. Demikian halnya dengan tujuan dibentuknya sistem lalu lintas adalah agar setiap komponen yang tergabung dalam lalu lintas dapat memiliki ruang masing-masing sehingga dapat mewujudkan lalu lintas dan angkutan jalan yang selamat, aman, cepat, lancar, tertib dan teratur, nyaman dan efisien yang keseluruhannya dilakukan dalam suatu manajemen lalu lintas dan angkutan jalan.

Dalam hal ini, kegiatan manajemen dan rekayasa lalu lintas tersebut diperankan oleh masingmasing Kepolisian Resort yang disingkat dengan Polres setempat dengan unit Sat Lantas sebagai kepanjangtanganannya, yang bekerja sama dengan Dinas Lalu Lintas dan Angkutan Jalan (DLLAJ) sebagai pelopor kegiatan berlalu lintas. Hal ini dipertegas dengan adanya aturan dari Pemerintah yang mengatur tentang tata cara berlalu lintas yang dituangkan di dalam Undang-Undang Nomor 22 Tahun 2009 tentang Lalu Lintas dan Angkutan Jalan.

Undang-undang Lalu Lintas tersebut menegaskan peran serta pemerintah sebagai fasilitator dalam mengatur sistem arus lalu lintas sehingga tercipta kondisi yang tertib dan teratur dan dapat mewujudkan cita-cita bangsa.

Sebagai penjabaran dari Undang-Undang Lalu Lintas dalam mengatur pergerakan dari masingmasing komponen adalah adanya tindakan manajemen lalu lintas yang meliputi kegiatan berupa perencanaan, pengaturan, pengawasan, dan pengendalian lalu lintas yang bertujuan untuk keselamatan, keamanan, ketertiban, dan kelancaran lalu lintas yang dilakukan dengan berbagai macam usaha-usaha manajemen lalu lintas oleh masing-masing stakeholder yang berkaitan fungsinya dengan sistem lalu lintas dan angkutan jalan.

Manajemen lalu lintas sendiri yang merupakan pengaturan dalam gerak arus lalu lintas.Akan tetapi pada saat ini, ruang gerak dari lalu lintas dirasakan semakin sesak dikarenakan semakin tingginya volume kendaraan mengakibatkan timbulnya berbagai masalah baru yang lebih kompleks dihadapi oleh masyarakat.

Permasalahan tersebut dapat dilihat dari jumlah kemacetan yang semakin meningkat serta tingginya jumlah kecelakaan, Hal demikian menimbulkan dampak yang negatif dari bagi masyarakat, dari tertundanya pengiriman barang dan jasa karena mendapati kemacetan di jalan, hingga meningkatnya angka kecelakaan yang berakibat kerugian baik material, immaterial bahkan mengakibatkan hilangnya nyawa seseorang akibat kecelakaan lalu lintas.

Di sadari bersama bahwa transportasi lalu lintas selama ini sudah menjadi bagian hidup yang tidak terpisahkan. Hampir setiap saat masyarakat bersentuhan dengan transportasi lalu lintas, karena pada dasarnya manusia adalah makhluk yang bergerak dan berpindah dari satu tempat ke tempat lainnya dengan menggunakan transportasi.

Di awal kemunculannya, transportasi lalu lintas banyak mendatangkan kemudahan bagi masyarakat, karena transportasi lalu lintas dapat mempermudah gerak masyarakat ataupun barang dari suatu tempat ke tempat lainnya.Setiap masyarakat dapat bergerak dengan cepat dalam waktu yang singkat dan dapat melakukan banyak pekerjaan dibantu dengan transportasi tersebut.Akan tetapi pada perkembangannya, transportasi lalu lintas tumbuh menjadi momok yang menimbulkan dampak positif dan dampak negatif bersamaan dengan timbulnya permasalahan-permasalahan akibat transportasi lalu lintas. 
Seiring dengan meningkatnya jumlah transportasi lalu lintas, permasalahan-permasalahan yang timbul, diantaranya tingginya volume kendaraan seiring dengan meningkatnya pertumbuhan masyarakat yang tidak dibarengi dengan pembangunan infrastruktur sehingga mengakibatkan menurunnya kualitas infrastruktur.

Dalam pembangunan negara Indonesia sendiri, pembangunan infrastruktur merupakan rencana pembangunan dari jaman penjajahan Belanda hingga saat ini. Segala macam pembangunan infrastruktur dilakukan di berbagai daerah termasuk pembangunan alat transportasinya.Akan tetapi pada faktanya, pembangunan infrastruktur tidak bisa mengimbangi pertumbuhan masyarakat dan perkembangan tekhnologi yang terus bergerak dengan cepat.

Salah satu pembangunan infrastruktur yang merupakan perkembangan pesat adalah adanya alat transportasi yang dapat mencukupi kebutuhan masyarakat luas yang hanya ada di kota-kota besar sehingga dapat mengurangi jumlah kendaraan yang berlalu lintas, yaitu Jakarta yang menjadi ibu kota Negara Indonesia dan beberapa kota besar lainnya seperti Bandung dan Semarang dan belum dapat mencapai kabupaten-kabupaten lainnya. Alat transportasi tersebut berupa busway.

$\mathrm{Hal}$ ini adalah suatu perkembangan yang pesat dalam dunia transportasi di Indonesia. Akan tetapi, sayangnya pembangunan infrastruktur tersebut hanya ada di kota besar. Pada faktanya, sebagai bentuk dari meningkatnya perekonomian di masyarakat adalah terjadi arus perpindahan barang dari kota satu ke kota lainnya. Perpindahan barang ini pada umumnya dilakukan dengan menggunakan alat angkut berupa Truk. Hal ini juga menimbulkan kendala dalam proses pengangkutannya.

Apabila kota besar mengenal alat transportasi jarak pendek berupa busway, dalam transportasi dengan jarak yang jauh untuk mengangkut barang dikenal dengan kendaraan berupa Truk sebagai alat mobilitas yang murah dan dapat mengangkut banyak barang. Tingginya arus lalu lintas dari kendaraan berupa Truck ini terlihat terutama di kota-kota yang dilewati jalur pantura dari Surabaya ke Jakarta ataupun sebaliknya bahkan dari jalur jalur selatan maupun sebaliknya.

Jalur pantura (Jalur Pantai Utara) adalah jalan utama di pulau Jawa yang merupakan Jalan Nasional Rute 1 yang melewati 5 (lima) provinsi sepanjang $1.316 \mathrm{~km}$ di sepanjang pesisir pantai utara Jawa, yaitu Banten, Jakarta, Jawa Barat, Jawa Tengah dan Jawa Timur. Rute ini menghubungkan dua pelabuhan penyeberangan yaitu pelabuhan merak di ujung barat pulau jawa dan Ketapang di ujung Timur pulau Jawa. ${ }^{3} \mathrm{Hal}$ ini mengakibatkan jalur pantura menjadi tulang punggung dari arus lalu lintas perpindahan barang dengan menggunakan truk.

Kabupaten Rembang merupakan salah satu kota yang berada digaris pantai utara pulau jawa sekaligus mejadi penghubung antar kota lainnya dan dilewati dengan jalur pantura sebagai jalur utama arus kendaraan berupa Truk. Sebagai kabupaten yang menjadi penghubung tentunya Kabupaten Rembang menjadi salah satu kota transit dari jaringan lalu lintas dan angkutan jalan, jika diliat dari sudut pandang perekonomian hal ini tentunya sangat membantu dengan statusnya sebagai kota transit tentunya banyak peluang usaha yang dapat dilakukan masyarakat sekitar, contohnya seperti membuka warung makan tepi jalan, namun disisi lain hadirnya kegiatan usaha warung makan tepi jalan tersebut membuat dampak lain yang dapat mengganggu arus lalu lintas contohnya seperti timbulnya parkir liar yang dilakukan oleh pengguna jalan.

Meningkatnya jumlah parkir liar tersebut dipicu adanya warung yang beroperasi di pinggiran jalur pantura dan tidak memiliki lahan parkir yang mengakibatkan para sopir truk terutamanya sopir truk memarkirkan kendaraan mereka di badan jalan Pantura.Banyak alasan dari parkir liar kendaraan tersebut diantaranya berhenti sejenak untuk makan, minum kopi, atau istirahat untuk tidur.

\footnotetext{
${ }^{3}$ http://id.wikipedia.org/wiki/jalan_Nasional_Rute_1 di akses pada tanggal 21 November 2017, Pukul 11.30
} 
Meningkatnya jumlah warung di pinggir jalan menandakan meningkatnya perekonomian di Kabupaten Rembang, karena banyak sekali pengguna jalan yang memanfaatkan adanya warungwarung tersebut sebagai tempat makan bahkan menjadi tempat singgah sementara sembari beristirahat memulihkan stamina.Istirahatnya para pengguna jalan di tepi jalan menimbulkan dampak negative, yaitu meningkatnya parkir liar di sepanjang tepi-tepi jalan di Kabupaten Rembang.

Dari segi bahasa sendiri, parkir pada umumnya adalah keadaan tidak bergerak dari suatu kendaraan yang bersifat sementara karena ditinggalkan oleh pengemudinya, sementara itu untuk mewujudkan lalu lintas yang tertib maka diperlukan pengelolaan parkir yang lebih baik mengingat pengelolaan parkir tersebut tidak hanya bertujuan untuk meningkatkan pelayanan serta mengatur pelaksanaan parkir kendaraan tepi jalan umum namun dapat menjadi sumber penghasilan dari daerah untuk meningkatkan perekonomian.

Secara umum kegiatan pengelolaan parkir diatur dalam peraturan daerah yang akan disesuaikan dengan kebutuhan daerah tersebut, Kabupaten Rembang sendiri mengatur kegiatan parkir dalam Peraturan Daerah Nomor 16 Tahun 2011 tentang Perubahan Atas Peraturan Daerah Kabupaten Rembang Nomor 4 Tahun 2010 tentang Retribusi Pelayanan Parkir di Tepi Jalan Umum. Dengan demikian parkir merupakan kegiatan yang diatur oleh hukum yang harus dipatuhi oleh segenap masyarakat, dimana dalam pelaksanaannya pengaturan tersebut dilaksanakan oleh Unit LLAJ (Lalu Lintas Angkutan Jalan) dari Dinas Perhubungan dan Satuan Lalu Lintas Polisi Resort Rembang. Keduanya merepukan institusi yang saling bekerja sama untuk menertibkan, mengatur serta menindak setiap pelanggaran yang timbul dalam lingkar Lalu Lintas.

Fungsi satuan lalu lintas dalam penyelenggaraan tugas pokok Polri dibidang lalu lintas meliputi ${ }^{4}$ :

1. Penegakan hukum lalu lintas (police Traffic Law Enforcement)

2. Pendidikan masyarakat tentang lalu lintas (Police Traffic Education)

3. Keteknikan lalu lintas (Police Traffic Engineering)

4. Registrasi/identifikasi pengemudi dan kendaraan (Drive And Vehicle Identification)

Pada dasarnya polisi lalu lintas bertugas mengawasi, membantu, menjaga agar sistem transportasi jalan raya berfungsi secara lancar ${ }^{5}$, selain itu petugas lalu lintas mempunyai hak untuk menindak secara tegas dan transparan ketika medapati pelanggaran yang terjadi dilapangan akibat dari masyarakat yang tidak mematuhi peraturan lalu lintas sehingga menimbulkan permasalahanpermasalahan di jalan.

Satjipto Rahardjo mengatakan, penegakan hukum merupakan suatu usaha untuk mewujudkan ide-ide dan konsep-konsep menjadi kenyataan ${ }^{6}$.dengan demikian setiap tindakan yang dilakukan oleh satuan polisi lalu lintas tidak lain adalah untuk mewujudkan cita cita hukum yang berkeadilan dengan berlandaskan Pancasila.

Fenomena parkir liar merupakan aktivitas yang dapat kita jumpai sehari hari, dan memang sangat mengganggu aktifitas dari pengendara lain, ini disebabkan karena menyempitnya ruas jalan karena dipergunakan sebagai lahan parkir liar.Hal demikian terjadi pula di Kabupaten Rembang.Berkurangnya ruas jalan karena dipergunakan untuk parkir liar dari kendaraan menimbulkan banyak permasalahan.Parkir liar yang dimaksud disini adalah, prilaku menghentikan kendaraan untuk sementara karena ditinggal oleh pengemudinya dimana penghentian kendaraan tersebut bukan pada

\footnotetext{
${ }^{4}$ http://sosrapolice.blogspot.com/2013/09/perananpolisi.html di akses pada tanggal 22 November 2017 pukul 20.00 WIB

${ }^{5}$ Andrew R, 2011. Penegakan Hukum Lalu Lintas, Bandung, Nuansa. hlm. 27

${ }^{6}$ Satjipto Rahardjo, 1983. Masalah Penegakan Hukum, Suatu Tinjauan Sosiologis.Jakarta:Rajawali press, hlm. 24
} 
fasilitas yang disediakan sehingga dapat berakibat pada terganggunya aktivitas lalu lintas secara menyeluruh baik karena macet ataupun karena kecelakaan.

Seperti yang diberitakan oleh detikNews Jumat 28 Juli 2017 seorang pemotor dirembang tewas seketika setelah menabrak bagian belakang truk gandeng yang sedang parkir ${ }^{7}$. Kegiatan parkir liar ini kebanyakan dilakukan di sepanjang jalur pantura di Kabupaten Rembang yang tidak sedikit memakan korban jiwa.Penindakannya pun dibutuhkan segera dengan menghadirkan solusi yang tepat tanpa merugikan siapa pun mengingat tujuan hukum untuk melahirkan keadilan, kepastian, dan kemanfaatan hukum disendi-sendi hidup masyarakat.

Salah satu permasalahan yang di hadapi oleh Satuan polisi lalu lintas (Satlantas) Polres Rembang sebagai penegak hukum yang terlibat langsung di lapangan adalah meningkatnya angka kecelakaan lalu lintas yang pada dasarnya disebabkan dari kurangnya kesadaran masyarakat khususnya pengemudi menjadi salah satu faktor masalah, mengingat penegakan hukum sendiri tidak terlepas dari peran masyarakat sebagai pelaksana kegiatan berlalu lintas dan angkutan jalan.

Dalam hal ini, Sat Lantas Polres Rembang menghadapi permasalahan yang cukup kompleks berkaitan dengan meningkatnya kecelakaan lalu lintas yang diakibatkan dari tingginya parkir liar. Adapun kondisi parkir liar truk tersebut telah terjadi cukup lama, akan tetapi tidak ada ketegasan dari Pemerintah setempat di Kabupaten Rembang dalam melakukan penegakan hukum terkait dengan tingginya parkir liar semakin memperparah permasalahan yang dihadapi. Padahal, keberadaan truk parkir di pinggir jalur pantura kabupaten Rembang tersebut dinilai membahayakan bagi para pengguna jalan.Selain mengurangi jumlah volume jalur pantura, keberadaannya terkadang tidak terlihat saat malam hari sehingga mengakibatkan kecelakaan.

Seiring dengan meningkatnya jumlah kecelakaan akibat parkir liar serta uraian diatas maka penulis tertarik untuk mengangkat judul "Peran Satlantas Polres Rembang Dalam Menanggulangi Tingginya Kecelakaan Akibat Parkir Liar".

Dari latar belakang sudah dijelasnya diatas maka penulis akan coba mengkaji permasalahan tersebut dengan mengangkat rumusan masalah sebagai berikut: 1) Bagaimana Peran dan Fungsi Satuan Lalu Lintas di Polres Rembang? 2) Bagaimana Teori Penegakan Hukum Sebagai Bentuk Penanganan Parkir Liar Penyebab Laka Lantas di Wilayah Hukum Polres Rembang? 3) Bagaimana konsep ideal penanganan parkir liar guna menekan tingkat kecelakaan lalu lintas diwilayah hukum Polres Rembang?

\section{PEMBAHASAN}

\section{Peran Dan Fungsi Satuan Lalu Lintas Tingkat Polres}

Kepolisian Negara Republik Indonesia atau yang biasa di singkat Polri merupakan alat Negara yang berperan dalam memelihara keamanan dan ketertiban masyarakat, menegakan hukum, serta memberikan perlindungan, pengayoman, dan pelayanan pada masyarakat dalam rangka terpeliharanya keamanan dalam negeri.

Satuan lalu lintas sendiri merupakan bagian dari polri yang merupakan unsur pelaksana tugas pokok yang berada di bawah Kapolres ${ }^{8}$.Selanjutnya lebih ditegaskan pada pasal 59 Peraturan Kapolri No. 23 Tahun 2010, dijelaskan bahwa Satlantas sebagaimana dijelaskan bahwa:

\footnotetext{
${ }^{7}$ https://news.detik.com/jawatengah/3578217/tabrak-truk-parkir-pemotor-di-rembang-tewas-seketikadi akses tanggal 23 November 2017, Pukul 14.00 WIB.

${ }^{8}$ Lihat Pasal 59 ayat 1 Peraturan Kepala Polisi Republik Indonesia Nomor 23 Tahun 2010 tentang Susunan Organisasi dan Tata Kerja Pada Tingkat Kepolisian Resort dan Kepolisian Sektor
} 
1. Satuan lalu lintas merupakan unsur pelaksana tugas pokok yang berada di bawah Kapolres.

2. Satlantas bertugas melaksanakan Turjawali lalu lintas, pendidikan masyarakat lalu lintas (Dikmaslantas), pelayanan registrasi dan identifikasi kendaraan bermotor dan pengemudi, penyidikan kecelakaan lalu lintas dan penegakan hukum di bidang lalu lintas.

3. Dalam melaksanakan tugas sebagaimana dimaksud pada ayat (2), Sat lantas menyelenggarakan fungsi:
a) Pembinaan lalu lintas kepolisian; pembinaan partisipasi masyarakat melalui kerja sama lintas sektoral, Dikmaslantas, dan pengkajian masalah di bidang lalu lintas;
b) Pelaksanaan operasi kepolisian bidang lalu lintas dalam rangka penegakan hukum dan keamanan, keselamatan, ketertiban, kelancaran lalu lintas (Kamseltibcarlantas);
c) Pelayanan administrasi registrasi dan identifikasi kendaraan bermotor sertapengemudi;
d) Pelaksanaan patroli jalan raya dan penindakan pelanggaran serta penanganan kecelakaan lalu lintas dalam rangka penegakan hukum, serta menjamin Kamseltibcarlantas di jalan raya;
e) Pengamanan dan penyelamatan masyarakat pengguna jalan; dan
f) Perawatan dan pemeliharaan peralatan dan kendaraan.

\section{Teori Penegakan Hukum Sebagai Bentuk Penanganan Parkir Liar Penyebab Laka Lantas Di Wilayah Hukum Polres Rembang}

Penegakan hukum merupakan usaha untuk mewujudkan ide-ide dan konsep konsep hukum yang diharapakan rakyat menjadi kenyataan. Penegakan hukum merupakan suatu proses yang melibatkan banyak hal. ${ }^{9}$ Sementara itu Sanyota mengatakan penegakan hukum ditujukan guna meningkatkan ketertiban dan kepastian hukum dalam masyarakat. Hal ini dilakukan antara lain dengan menertibkan fungsi, tugas dan wewenang lembaga-lembaga yang bertugas menegakan hukummenurut proporsi ruang lingkup masing-masing, serta didasarkan atas system kerjasama yang baik dan mendukung tujuan yang hendak dicapai. ${ }^{10}$

Penegakan hukum secara konkret adalah berlakunya hukum positif dalam praktik sebagaimana seharusnya patut dipatuhi. Oleh karena itu, memberikan keadilan dalam suatu perkara berarti memutuskan hukum in concreto dalam mempertahankan dan menjamin di taatinya hukum materiil dengan menggunakan cara procedural yang ditetapkan oleh hukum formal. ${ }^{11}$

Penegakan Hukum dibedakan menjadi dua yaitu : ${ }^{12}$

1. Ditinjau dari sujut subjeknya

Dalam arti luas, proses penegakkan hukum melibatkan semua subjek hukum dalam setiap hubungan hukum. Siapa saja yang menjalankan aturan normative atau melakukan sesuatu atau tidak melakukan sesuatu dengan mendasarkan diri pada norma aturan hukum yang berlaku, berarti dia menjalankan atau menegakkan aturan hukum.

Dalam arti sempit, penegakkan hukum hanya diartikan sebagai upaya aparatur penegakan hukum tertentu untuk menjamin dan memastikan bahwa suatu aturan hukum berjalan sebagaimana seharusnya.

2. Ditinjau dari segi objeknya, yaitu hukumnya

Dalam arti luas, penegakkan hukum yang mencakup pada nilai-nilai keadilan yang di dalamnya terkandung bunyi aturan formal maupun nilai-nilai keadilan yang ada dalam bermasyarakat.Dalam

\footnotetext{
${ }^{9}$ Dellyana,Shant, 1988, Konsep Penegakan Hukum. Yogyakarta, Liberty hal 32

${ }^{10}$ Sanyoto,Penegakan Hukum di Indonesia, Jurnal Dinamika Hukum, Vol. 8 No. 3 September 2008

${ }^{11}$ Ibid. hlm 33

${ }^{12}$ Ibid. hlm 34
} 
arti sempit, penegakkan hukum itu hanya menyangkut penegakkan peraturan yang formal dan tertulis.

Penegakan hukum merupakan usaha untuk mewujudkan ide-ide dan konsep-konsep hukum yang diharapakan rakyat menjadi kenyataan. Penegakan hukum merupakan suatu proses yang melibatkan banyak hal.

Joseph Goldstein membedakan penegakan hukum pidana menjadi 3 bagian yaitu: ${ }^{13}$

1. Total enforcement, yakni ruang lingkup penegakan hukum pidana sebagaimana yang dirumuskan oleh hukum pidana substantif (subtantive law of crime). Penegakan hukum pidana secara total ini tidak mungkin dilakukan sebab para penegak hukum dibatasi secara ketat oleh hukum acara pidana yang antara lain mencakup aturanaturan penangkapan, penahanan, penggeledahan, penyitaan dan pemeriksaan pendahuluan. Disamping itu mungkin terjadi hukum pidana substantif sendiri memberikan batasan-batasan. Misalnya dibutuhkan aduan terlebih dahulu sebagai syarat penuntutan pada delik-delik aduan (klacht delicten). Ruang lingkup yang dibatasi ini disebut sebagai area of no enforcement.

2. Full enforcement, setelah ruang lingkup penegakan hukum pidana yang bersifat total tersebut dikurangi area of no enforcement dalam penegakan hukum ini para penegak hukum diharapkan penegakan hukum secara maksimal.

3. Actual enforcement, menurut Joseph Goldstein full enforcement ini dianggap not a realistic expectation, sebab adanya keterbatasanketerbatasan dalam bentuk waktu, personil, alat-alat investigasi, dana dan sebagainya, yangkesemuanya mengakibatkan keharusan dilakukannya discretion dan sisanya, inilah yang disebut dengan actual enforcement.

\section{Konsep Ideal Penanganan Parkir Liar Guna Menekan Tingkat Kecelakaan Lalu Lintas Diwilayah Hukum Polres Rembang.}

Sebagai salah satu bagian yang penting dari manajemen lalu lintas khususnya yang menyangkut parkir adalah pengawasan.Pengawasan merupakan suatu hal yang harus dilaksanakan secara tegas dan dilakukan secara terus menerus, sebab kalau tindakan terhadap pelanggar tidak dilakukan, pelanggaran akan diulangi oleh masyarakat karena merasa tidak mendapatkan hukuman terhadap pelanggaran yang mereka lakukan.

Impementasi dalam menciptakan manajemen parkir harus dibutuhkan setidaknya kawasan ruang di luar parkir jalan seperti halaman, gedung, atau taman parkir yang menjadi sauatu syarat yang dapat di fungsikan sebagai lahan parkir serta dengan dibinanya para juru parkir yang seharusnya legal dan terdaftar pada pemerintah daerah Kabupaten Rembang serta menjamin juga kesejahteraan tukang parkir itu sendiri.

Otonomi daerah itu hanya dilihat sebagai persoalan manajemen atau administratif dalam arti sempit, maka besar kecilnya kewenangan yang dimiliki daerah otonom merupakan persoalan teknis administratif pemerintahan semata. Misalnya soal kewenangan pelayanan publik yang hampir semuanya diberikan kepada daerah otonom kabupaten/ kota karena secara objektif manajerial tugastugas tersebut lebih efisien dan efektif jika dilakukan secara otonom oleh daerahyang bersangkutan, daripada oleh tingkatan pemerintahan yang lebih tinggi. Tata laksana pemerintahan yang baik seperangkat proses yang diberlakukan dalam organisasi baik swasta maupun negeri untuk menentukan keputusan. Tata laksana pemerintahan yang baik ini walaupun tidak dapat menjamin sepenuhnya segala sesuatu akan menjadi sempurna. ${ }^{14}$

\footnotetext{
${ }^{13}$ Ibid. hlm 39

${ }^{14}$ Winarno, Budi, Globalisasi Peluang atau Ancaman Bagi Indonesia, ( Jakarta: PT Gelora aksara Pratama,2008) hal.44
} 
Selain itu ada beberapa hal yang harus diperhatikan sebagai konsep ideal penanganan parkir liar yaitu :

1. Pengendalian penyediaan ruang parkir

Salah satu langkah penting dalam pengendalian lalu lintas adalah dengan membatasi ketersediaan ruang parkir sebagai berikut :

a. Pengurangan fasilitas parkir di pinggir jalan sebagaimana diamanatkan didalam Undang-undang No. 22 tahun 2009 tentang Lalu Lintas dan Angkutan Jalan dalam pasal 43 ayat (3) yang berbunyi Fasilitas Parkir di dalam Ruang Milik Jalan hanya dapat diselenggarakan di tempat tertentu pada jalan kabupaten, jalan desa, atau jalan kota yang harus dinyatakan dengan Rambu Lalu Lintas, dan/atau Marka Jalan. atau lebih ekstrem menghilangkan fasilitas parkir dipinggir jalan. ${ }^{15}$

b. Merubah pendekatan dalam pemberian ljin Mendirikan Bangunan untuk tempat-tempat umum, perkantoran atau pertokoan dengan merubah pendekatan dari jumlah ruang parkir minimal menjadi jumlah ruang parkir maksimal.

c. Bangunan tidak diperkenankan untuk menyediakan fasilitas ruang parkir, agar pengguna bangunan tersebut menggunakan angkutan umum.

2. Kebijakan waktu

Kebijakan pembatasan parkir paruh waktu Pembatasan parkir dapat dilakukan dengan menerapkan pembatasan waktu yang dilakukan dengan :

a. Penetapan waktu parkir maksimal, yang biasanya dilakukan pada parkir dipinggir jalan dengan menggunakan mesin parkir, dimana parkir untuk waktu yang panjang tidak dijinkan, parkir diarahkan untuk jangka pendek misalnya parkir untuk makan siang atau parkir untuk belanja di toko.

b. Penetapan larangan parkir pada waktu-waktu tertentu, misalnya dilarang parkir pada jam sibuk pagi atau jam sibuk sore, dimana jalan lebih diperuntukkan untuk mengalirkan arus lalu lintas. Penetapan seperti ini biasanya dilakukan untuk jalan-jalan yang masih diijinkan untuk parkir dipinggir jalan tetapi kapasitas jalannya terbatas sehingga untuk meningkatkan kapasitas pada waktu-waktu tertentu maka parkir dipinggir jalan dilarang.

3. Pengawasan Parkir

Pelaksanaan pengawasan yang disertai dengan penegakan hukum yang tegas merupakan langkah yang penting dalam pengendalian parkir untuk mempertahankan kinerja lalu lintas.

Langkah yang penting dalam pengawasan parkir antara lain meliputi penilangan pelanggaran parkir oleh Polisi Lalu Lintas, pemasangan gembok roda sehingga dapat menimbulkan efek jera bagi pelanggar terhadap larangan parkir ataupun penderekan terhadap kendaraan yang mogok atau melanggar larangan parkir.

Sebagai unsur penting dalam lalu lintas jalan salah satu kebijakan sistem parkir otomatis memiliki keunggulan yaitu :

a. Sistem perparkiran lebih aman, karena kendaraan yang masuk selalu terdata secara tercatat maupun gambar.

b. Mengurangi antrian kendaraan, karena cara kerja system lebih banyak bersifat otomatis dibandingkan dengan cara manual.

c. Mengurangi terjadinya kesalahan, karena operator hanya perlu menginput nomor kendaraan saja.

d. Mengurangi biaya operasional, karena menggunakan kartu parkir elektronik (Barcode Card) yang dapat dipakai berulang kali (Repeatable).

\footnotetext{
${ }^{15}$ Undang-undang No. 22 tahun 2009 tentang Lalu Lintas dan Angkutan Jalan pasal 43 ayat (3)
} 
e. Mudah dalam membedakan pengguna area parkir, karena kartu parkir dapat dikelompok sesuai dengan kebutuhan, misalnya: umum, member, karyawan, dll.

f. Mudah mengetahui jumlah kendaraan yang berada di area parkir, karena system selalu memberikan informasi secara real time.

g. Mudah dalam melakukan perubahan jika terjadi perubahan ketentuan perparkiran, karena system sudah dilengkapi dengan fasilitas setting ketentuan parkir.

h. Mudah dalam mengantisipasi bila terjadi hal-hal yang tidak diinginkan, misalnya dengan melakukan blokir nomor kartu parkir, membunyikan alarm, dll.

i. Mudah dalam mengetahui pendapatan parkir, karena pengolahan data dilakukan secara real time.

j. Mudah dalam melakukan evaluasi dan rencana pengembangan area parkir, karena lengkapnya data yang terkumpul.

Penulis mencoba mengutarakankonsep ideal dalam penanganan parkir liar. Yakni Strategi Pengelolaan Parkir (On The Street). Dalam mengurangi Kecelakaan Lalu Lintas yang secara terencana, terorganisir dan terintegrasi. Yakni swastanisasi sektor parkir dengan menciptakan Parking Building Unit (PBU) dengan konsep yakni Pola Penyediaan Minimum (Minimum Parking Provision) yakni adalah penyediaan fasilitas minimum sector kebutuhan ruang parkir oleh pelaku usaha yang disebut dengan parkir khusus dimana aktifitas parkir khusus oleh pelaku usaha mampu memperkirakan standar jumlah minimum pengunjung aktifitas parkirnya kemudian yang kedua yaitu; pola Penyediaan Maksimum (Maksimum Parking Provision) yakni adalah pembatasan jumlah kendaraan terhadap daya tampung maksimal sector ruang parkir khusus pelaku usaha sehingga apabila jumlah maksimum lebih daripada kuota yang disedikan maka kendaraan tidak diizinkan untuk parkir sehingga penngguna kendaraan pribadi akan selalu mempertimbangkan apakah perlu menggunakan kendaraan pribadi atau tidak.

Apabila hal ini dilanggar oleh pengguna jalan ataupun pelaku usaha yang menggunakan konsep parkir khusus maka kita menerapkan konsep Deficiency Charge yaitu membayar retribusi kepada pemerintah atas kekurangan jumlah ruang parkir yang disediakan oleh pelaksana parkir khusus ataupun pengguna jalandengan nominal yang akan ditentukan oleh pemerintah kabupaten Rembang. Akan tetapi penerapan pola ini harus bisa menjamin bahwa masyarakat tetap bisa mengakses lokasilokasi tersebut agar dapat dijangkau, antara lain dengan penyedian serta peningkatan moda transportasi umum yang sudah dikembangkan dengan baik. Berdasarkan UU 22 Tahun 2009 dijelaskan bahwa pola penyediaan batasan ruang parkir maksimal merupakan salah satu upaya dari manajemen kebutuhan lalu lintas (transportasi demand management), sehingga konsep ideal penanganan parkir liar dalam menanggulangi tingginya angka kecelakaan lalu lintas dapat tercapai.

\section{PENUTUP}

\section{Kesimpulan}

Dari hasil penelitian dan data konsep ideal penanganan parkir liar dalam menanggulangi tingginya angka kecelakaan lalu lintas sebagai upaya menekan angka kecelakaan lalu lintas di wilayah Polres Rembangpenulis menyimpulkan beberapa hal sebagai berikut :

1. Peran dan Fungsi Satuan Lalu Lintas di Polres Rembang.

Satuan lalu lintas sendiri merupakan bagian dari polri yang merupakan unsur pelaksana tugas pokok yang berada di bawah Kapolres. Selanjutnya lebih ditegaskan pada pasal 59 Peraturan Kapolri No. 23 Tahun 2010, dijelaskan bahwa Satlantas sebagaimana dijelaskan bahwa:

a. Satuan lalu lintas merupakan unsur pelaksana tugas pokok yang berada di bawah Kapolres. 
b. Satlantas bertugas melaksanakan Turjawali lalu lintas, pendidikan masyarakat lalu lintas (Dikmaslantas), pelayanan registrasi dan identifikasi kendaraan bermotor dan pengemudi, penyidikan kecelakaan lalu lintas dan penegakan hukum di bidang lalu lintas.

c. Dalam melaksanakan tugas sebagaimana dimaksud pada ayat (2), Sat lantas menyelenggarakan fungsi:

1) Pembinaan lalu lintas kepolisian;

2) Pelaksanaan operasi kepolisian bidang lalu lintas dalam rangka penegakan hukum dan keamanan, keselamatan, ketertiban, kelancaran lalu lintas (Kamseltibcarlantas);

3) Pelayanan administrasi registrasi dan identifikasi kendaraan bermotor sertapengemudi;

4) Pelaksanaan patroli jalan raya dan penindakan pelanggaran serta penanganan kecelakaan lalu lintas dalam rangka penegakan hukum, serta menjamin Kamseltibcarlantas di jalan raya;

5) Pengamanan dan penyelamatan masyarakat pengguna jalan; dan

6) Perawatan dan pemeliharaan peralatan dan kendaraan.

2. Teori Penegakan Hukum Sebagai Bentuk Penanganan Parkir Liar Penyebab Laka Lantas di Wilayah Hukum Polres Rembang

a. penegakkan hukum hanya diartikan sebagai upaya aparatur penegakan hukum tertentu untuk menjamin dan memastikan bahwa suatu aturan hukum berjalan sebagaimana seharusnya

b. Penegakan hukum merupakan usaha untuk mewujudkan ide-ide dan konsep-konsep hukum yang diharapakan rakyat menjadi kenyataan. Penegakan hukum merupakan suatu proses yang melibatkan banyak hal

3. Konsep Ideal Penanganan Parkir Liar Guna Menekan Tingkat Kecelakaan Lalu Lintas Diwilayah Hukum Polres Rembang.

Strategi Pengelolaan Parkir (On The Street). Dalam mengurangi Kecelakaan Lalu Lintas yang secara terencana, terorganisir dan terintegrasi.Yakni swastanisasi sektor parkir dengan menciptakan Parking Building Unit (PBU) dengan konsep yakni Pola Penyediaan Minimum (Minimum Parking Provision); pola Penyediaan Maksimum (Maksimum Parking Provision) dankonsep Deficiency Charge.pola penyediaan batasan ruang parkir maksimal merupakan salah satu upaya dari manajemen kebutuhan lalu lintas (transportasi demand management), sehingga konsep ideal penanganan parkir liar dalam menanggulangi tingginya angka kecelakaan lalu lintas dapat tercapai.

\section{Saran}

Berdasarkan kesimpulan tersebut diatas, maka dikemukakan beberapasaran sebagai berikut :

1. Perlu diadakan pembenahan parkir tidak resmi secara intensif sehinggapengelolaan parkir tepi jalan umum lebih optimal dan tertib.

2. Mengusulkan tim terpadu yang terdiri dari pemerintah daerah kabupaten Rembang. Yang terdiri dari Kepolisian,SatpolPP, Dinas Perhubungan, Camat dan Lurah setempat yangbisa bekerjasama dalam penanganan tukang parkir tidak resmisehingga pengawasan di bidang perparkiran lebih efisien dan bisamembuat nyaman masyarakat.

3. Penyediaan sarana dan prasaranauntuk juru parkirlmplementasi kebijakan pemungutanretribusi pelayanan parkir di tepi jalanumum kurang maksimal pelaksanaannyakarena minimnya sarana dan prasarana, sehingga perlu disediakan sarana dan prasarana parkir bagi pengusaha maupun petugas parkir.

4. Sosialisasi kepada masyarakat tentang keteriban lalu lintas khususnya tentang parker liar, sehingga masyarakat dapat menggunakan tempat parkir yang telah disediakan secara resmi. 


\section{DAFTAR PUSTAKA}

Andrew R, 2011. Penegakan Hukum Lalu Lintas, Bandung, Nuansa

Satjipto Rahardjo, 1983. Masalah Penegakan Hukum, Suatu Tinjauan Sosiologis.Jakarta:Rajawali press

Winarno, Budi, Globalisasi Peluang atau Ancaman Bagi Indonesia, ( Jakarta: PT Gelora aksara Pratama,2008)

Undang-Undang Dasar Negara Republik Indonesia Tahun 1945

Undang-Undang Nomor 2 Tahun 2002 tentang Kepolisian Negara Republik Indonesia

Undang-undang No 22 tahun 2009 tentang Lalu Lintas dan Angkutan Jalan

PP No. 55Tahun2012TentangKendaraan

Vademikum Polisi Lalu Lintas, Cetakan Pertama, Disahkan dengan surat keputusandirektur lalu lintas Polri tahun 2009

Peraturan Kepala Polisi Republik Indonesia Nomor 23 Tahun 2010 tentang Susunan Organisasi dan Tata Kerja Pada Tingkat Kepolisian Resort dan Kepolisian Sektor

Dellyana,Shant, 1988, Konsep Penegakan Hukum. Yogyakarta, Liberty

Sanyoto,Penegakan Hukum di Indonesia, Jurnal Dinamika Hukum, Vol. 8 No. 3 September 2008

http://id.wikipedia.org/wiki/jalan_Nasional_Rute_1

http://sosrapolice.blogspot.com/2013/09/perananpolisi.html

https://news.detik.com/jawatengah/3578217/tabrak-truk-parkir-pemotor-di-rembang-tewas-seketika 